\title{
MOULT OF PRIMARIES AND RECTRICES IN THE GREATER FRIGATEBIRD, FREGATA MINOR, ON GENOVESA, GALÁPAGOS
}

\author{
by \\ J. DE KORTE \\ Institute of Taxonomic Zoology, University of Amsterdam, The Netherlands \\ $\&$ \\ TJ. DE VRIES \\ Departamento de Biologia, Universidad Católica, Ap. 2184, Quito, Ecuador
}

\begin{abstract}
Greater Frigatebirds with eggs and nestlings have a complete set of primaries and rarely show active moult in rectrices. In the wing serial descendant moult can be recognized; moult may be interrupted at any primary. The tail moult shows no detectable pattern.

Non-breeding adults and subadults were nearly all found moulting primaries and/or rectrices. The length of the different feather generations in the primaries is shorter in adults than in subadults. At most two primaries in one wing were found growing at the same time, whereas as many as four rectrices did. Some moult inner rectrices first, but others moult asymmetrically.
\end{abstract}

\section{RESUMEN}

Las Fragatas Pequeñas (Fregata minor) en la Isla Genovesa (Islas Galápagos) en la época de reproducción (sea con huevo o con un juvenil todavía no volador) tienen sus plumas primarias completas y rara vez muestran muda activa en las plumas remeras. Se observó en las alas una muda descendiente en dos o tres series, la misma que puede ser interrumpida en cualquiera de las primarias. La muda de la cola no muestra un patrón detectable.

Los adultos no reproductores y subadultos fueron encontrados casi todos con sus primarias y/o remeras en el proceso de muda. La longitud de las diferentes generaciones de las plumas primarias (o sea el largo de las diferentes series de muda en las primarias) es más corta en los adultos que en los subadultos. Fueron encontradas máximo dos primarias en una sola ala creciendo al mismo tiempo; mientras tanto, en la cola se observó crecer hasta cuatro plumas. Algunas mudan las remeras desde dentro, pero en otros individuos encontramos la muda asimétrica en la cola, sin patrón alguno.

Para la traducción en español del texto de las figuras, véase el apéndice.

\section{INTRODUCTION}

The island of Genovesa (Tower) is situated in the northeastern part of the Galápagos Archipelago. On this island $\left(17 \mathrm{~km}^{2}\right)$ there are several agglomerations of breeding pairs of Greater Frigatebirds, Fregata minor Gmelin, 1789. In 1975 the total population was estimated to be between 2000 and 3000 breeding pairs (Coello et al., 1977). Some of the breeding sites are situated in Darwin Bay, an area visited by tourists. In this tourist area, and also in an undisturbed control area, a ringing project and a study of ecology was started in 1975 (Coello et al., 1977).

In 1977 we worked in Darwin Bay from 28 July until 5 August. That time there were in the tourist area between the marked posts numbered 1-10 (which are stakes, placed by the Galápagos National Park Service, to guide visitors, keeping them in restricted areas) about 160 breeding pairs and in the control area some 50 breeding pairs. The main aim of De Vries was a study of tourist impact on Greater Frigatebirds, that of De Korte a study on klepto-parasitism in Greater Frigatebirds (De Korte, in preparation). In the meantime we continued the ringing project and we made a study of the moult of primaries and rectrices.

According to Dorward (in Stresemann \& Stresemann, 1966: 310), Diamond (1971) and Nelson (1975), Frigatebirds do not moult when they have eggs or young. However, Coello et al. (1977) investigated eight adults with young and found active tail feather moult in one. According to Stresemann \& Stresemann (1966) primary moult is serially descendent ("Staffelmäuser"). These authors distinguish in an adult wing three different feather generations, which are called $c, b$, a from the carpal joint outward; $c$ is replacing $b$ and $b$ is replacing $a$, etc. When the birds get older the distance between the moult waves is supposed to become smaller. Coello et al. (1977: 87, fig. 7) 


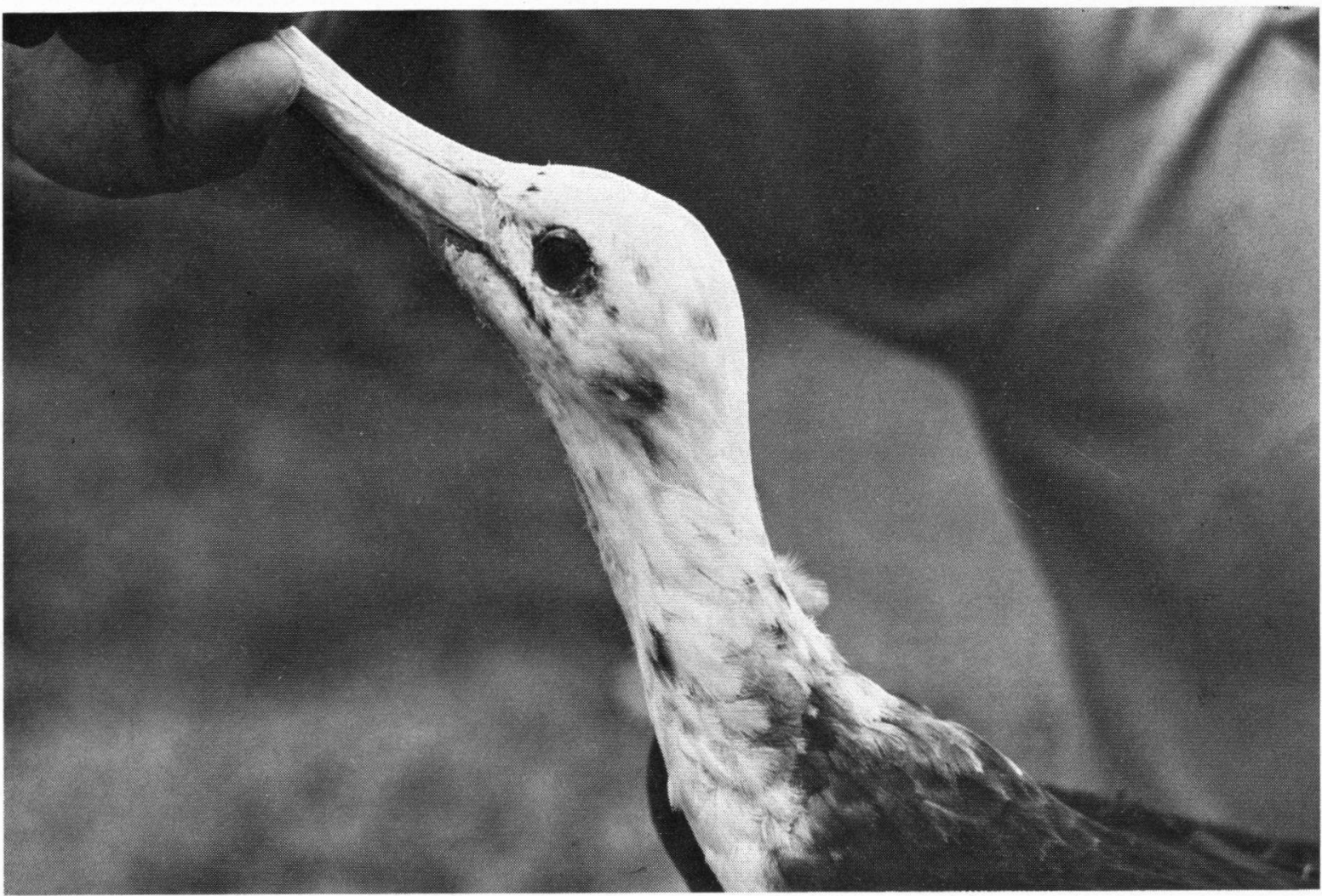

Fig. 1. Female subadult Greater Frigatebird, Genovesa, August 1977. Photograph J. de Korte.

present a figure of eight adults with young, which does not support these assumptions. Taking into account the deviating views, it seemed useful to look at the primary moult and also at the moult of rectrices, which until now has been little known.

\section{METHODS}

It is easy to catch a breeding Frigatebird with egg or small young because the bird stays on the nest when approached by a human being. It is more difficult to catch the parents of large young and of fledged juveniles, such juveniles themselves, and subadults. However, if one moves smoothly and slowly in the direction of the bird, grabbing at the bird very quickly in the last meter of approach, it is possible to catch the greater part of the birds aimed at.

Adult males and females are easy to distinguish from each other because of differences in plumage (Nelson, 1975). Subadults are characterized by a white head (fig. 1), which has progressively more black feathers as it becomes older (fig. 2). Sub- adults and fledged juveniles can be sexed by measuring bill length; females have a significantly larger bill than males (Nelson, 1975; Coello et al., 1977). In our total catch subadults are overrepresented in comparison with their numerical occurrence in the colony. We caught these subadults by preference as they showed active moult most clearly.

When looking at moult we stretched the wing and spread the tail and studied the upper- and undersides. The underside showed the moult pattern most clearly because here it was easier to distinguish between older and newer feathers, although sometimes, especially in breeding birds, the distinction proved to be difficult. It turned out that light intensity and light fall are important for ascertaining relative feather age. After 17.00 $h$, one hour before sunset, and also during overcast wheather, this can become difficult. This is the reason why we do not use all the moult data we have collected in the sequel.

Frigatebirds have 11 primaries, but $P_{11}$, the 


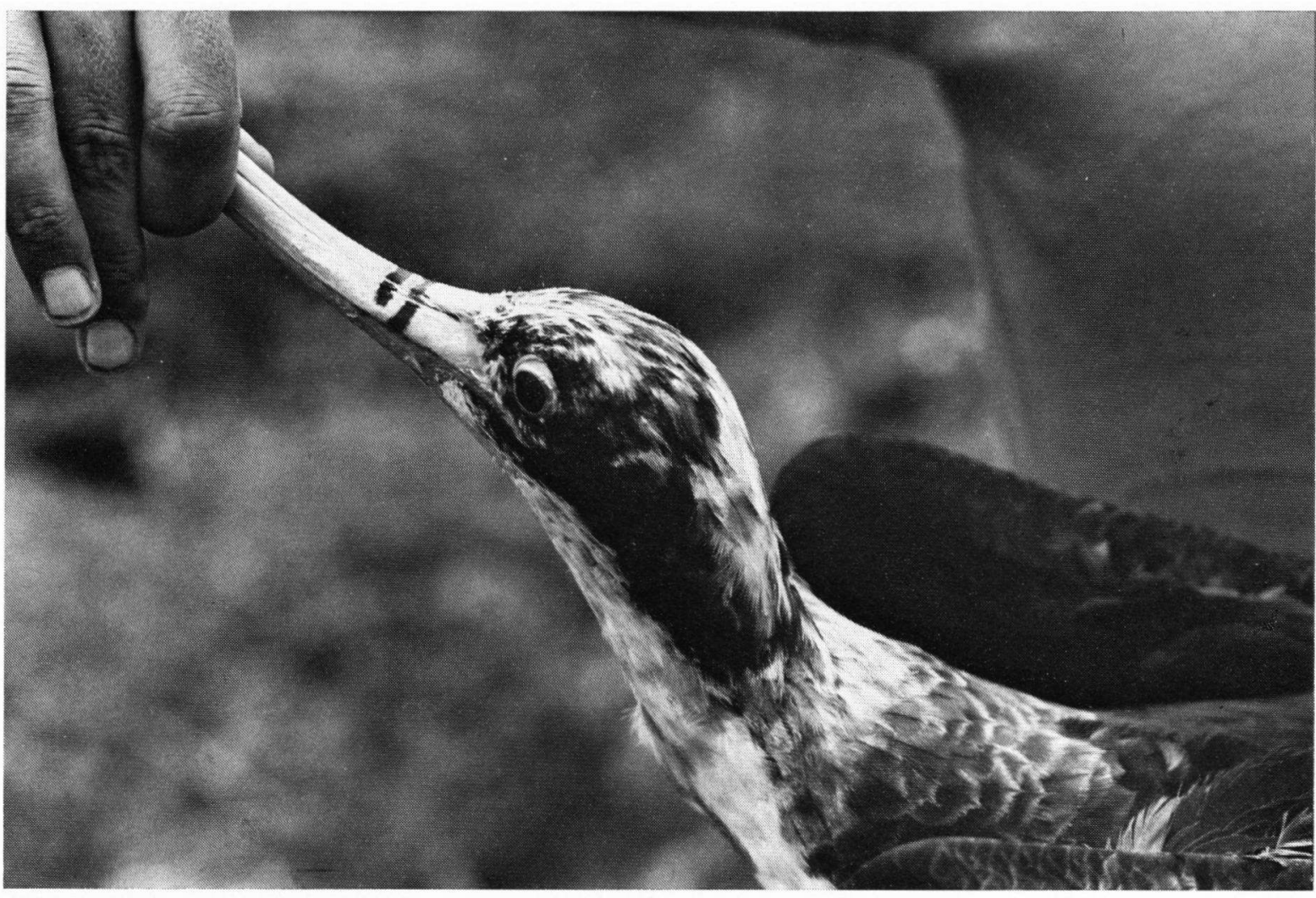

Fig. 2. Female subadult Greater Frigatebird with identification mark, Genovesa, August 1977. Photograph J. de Korte.

remicle, is shorter than the primary coverts. We did not look for this minute primary but confined ourselves to the first ten. In looking at moult we tried to ascertain the disruptions in the sequence of age of the feathers and to find the oldest and newest feather of every feather generation. After having ringed and studied the bird we gave it a clearly visible mark on the upper mandible (fig. 2) so as to avoid catching the same bird twice. Of some birds it was difficult to ascertain whether they were breeding or not. These were birds in adult plumage, caught when they were sitting somewhere without eggs or young. It was tempting to consider these birds as non-breeding adults, but in one case we saw a bird, that we had marked as a non-breeder previously, feeding a fledged juvenile.

\section{RESULTS}

We caught a total of 99 birds. Two were fledged juveniles, still fed by parents, 21 were subadults, probably of different ages, 14 were birds in adult plumage that probably were non-breeding, and 62 were breeding birds with eggs or young. Both fledged juveniles had a complete set of primaries and rectrices, all of which were of the same age. Of the birds in subadult plumage $(2$ males, 19 females), 2 males and 12 females had active moult of both primaries and rectrices, 3 females of primaries only, 3 of rectrices only and 1 female had a complete set of primaries and rectrices. Of the "presumed non-breeding birds" in adult plumage ( 4 males, 10 females), 3 males and 3 females showed active moult of both primaries and rectrices; 1 female of primaries only and 2 females of rectrices only, whereas 4 females and 1 male had a complete set of primaries and rectrices. All breeding birds ( 6 males with egg, 24 males with young, 8 females with egg, 24 females with young) had a complete set of primaries. One female with young showed active moult of tail feathers, while 6 males and 1 female had broken outer rectrices but did not moult.

Moult of primaries of 20 subadults is presented 
PRIMARIES

12345678910

q $R L 15 / 160000000$

Q $R \quad 000001 / 20000$

L 0000000000

Ó $R L \quad 1 / 20000 \% 000$

Q $R, 01 / 200001 / 2000$

$L \quad 1 / 200000000$

ㅇ $R L \quad 1 / 20000000^{1 / 2}$

$q^{R}{ }_{L} 8^{15 / 16}=0000000000$

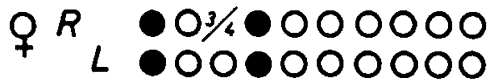

$q^{R} L 000000000 \%$

$q^{R} L 0000000000$

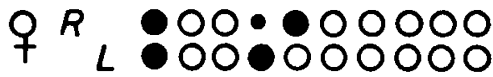

$\delta R L 000 \% 000000$

q RL $000 \%$ 1 $00000 \%$

q RL $0000 \cdot 00000$

P R L

qRL $0000 \% 1600000$

\& RL 0000000000

qRL 0000000000

qRL 0000000000

O RL $00000 \% 0000$

qRL $0000003 / 4000$
RECTRICES

$L$

$R$

654321123456

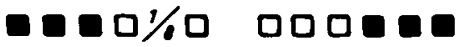

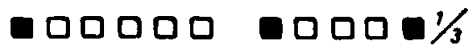

1/16001/200 00000

ดםอם

- $001 / 20$ D

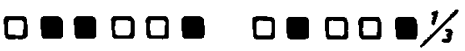

$00003 / 4$ व日000

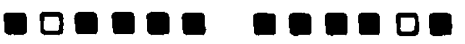

000\%00 001/4000

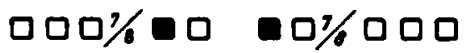

000ם3/4/4 81/40000

000000 1/400000

ם

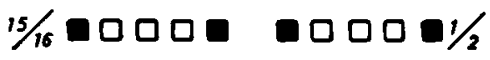

ロロロロ・ ロ ロロロロ\%

ロ \% \%ם

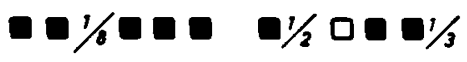

ם

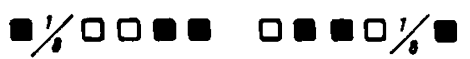

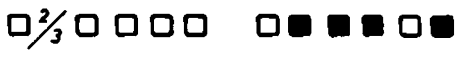

- $a b \quad \bullet C D$ De

Fig. 3. Moult of primaries and rectrices ( $R$ is right, $L$ is left) of 20 subadults; moult waves proceed from innermost $\left(P_{1}\right)$ to outermost primaries; $a=$ oldest primary in a feather generation, $b=$ other primaries, $c=$ feather absent, $d=$ relatively old rectrix, e = relatively new rectrix, $1 / 2=$ feather half grown, etc. 
in fig. 3, left. The individual birds are arranged in a sequence of active moult, starting with $P_{1}$. In this figure the oldest feather in a feather generation is denoted by a closed circle, other feathers are denoted by open circles. As moult proceeds descendantly, $\mathrm{P}_{1}$ is always the oldest feather of the innermost feather generation. For example, in the second bird of fig. $3, P_{1}$ has just been renewed, but it is the oldest feather of the innermost generation. $\mathrm{P}_{2}$ is the oldest feather in the next generation. Within one feather generation the wing feathers become progressively newer in distal direction.

Moult of rectrices of the same 20 subadults is presented in fig. 3, right. The age of the rectrices is denoted by closed (relatively old) or open (relatively new) squares. Thirteen birds had active moult in both wing and tail, 3 in the wing only and 3 in the tail only. One bird did not show any moult at all. Twelve birds moulted (active or arrested) their wings symmetrically. Six of the 16 birds with active primary moult had 2 primaries missing and/or growing simultaneously in the same wing. The length of a feather generation (innermost and outermost generation excluded) was rather variable ( 5 to 8 feathers).

Of the 16 birds with active tail moult, 5 showed symmetrical moulting of the rectrices (one feather on each side). All other birds with active tail moult had 1, 2 or 3 feathers growing asymmetrically. Three birds showed the central tail feathers to be the younger, but in the other instances we did not detect a regular pattern. Sequence of primary moult seems to be independent of sequence in rectrix moult. Growing $P_{1}$ may coincide with a variety of combinations of growing tail feathers.

The moult of 8 "presumed non-breeding adults" is presented in fig. 4. Six birds had active moult in both wing and tail. Two did not show active moult at all. Two birds moulted (1 active, 1 arrested) their wings symmetrically. In 1 bird 2 primaries were missing and one was growing simultaneously in the same wing. In 2 birds 2 primaries were growing simultaneously in the same wing. In 1 bird 1 primary was missing and 1 was growing. The length of a feather generation (innermost and

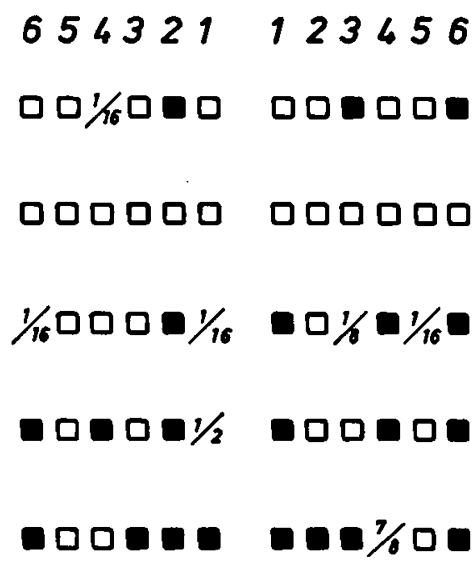

O $^{R} L$ Q $1 / 1800000001 / 2900$

QRL 1000000000

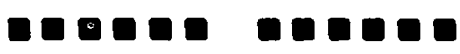

$q^{R L}-000000 \%$

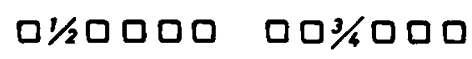

ÓR L $80000 \%$

ロ ロ・ロ ロ ロ

Fig. 4. Moult of primaries and rectrices of 8 "presumed non-breeding adults"; legends as in fig. $\hat{j}$. 
outermost excluded) was variable ( 2 to 6 feathers). None of the birds moulted its rectrices symmetrically. In one tail we found 4 rectrices growing simultaneously. This high number of growing tail feathers demonstrates the difficulty of analyzing the moult pattern in birds with arrested moult, where we found at times birds with a set of feathers that all seemed to be of the same age.

Moult of primaries of 36 breeding birds either with egg or young is presented in fig. 5. None of these birds had active moult of primaries. Nineteen birds had moulted their primaries in both wings symmetrically. In the asymmetrical instances most often 1 or 2 primaries were a feather ahead in one wing compared with the other. In 8 birds in one wing one more feather generation was found than in the other wing. At most, feathers of 4 generations were found in a single wing. The lengths of different feather generations (innermost and outermost excluded) were variable ( 2 to 7 feathers). Moult of rectrices is not shown in fig. 5 as all these birds had an arrested rectrix moult and the relative age of the rectrices was very difficult to estimate.

\section{DISCUSSION}

Apparently Greater Frigatebirds do not moult their primaries when they have eggs or flightless young. This is in accordance with the observations of Dorward (in Stresemann \& Stresemann, 1966), Diamond (1971) and Nelson (1975). These authors also did not record rectrix moult in breeding birds. Out of 62 breeding birds we found 1 female with young showing active rectrix moult; amongst 8 birds Coello et al. (1977) found 1 male with young having active rectrix moult.

After the young has fledged the parents continue to feed it for up to a year; the whole breeding cycle lasts at least 14 months (Nelson, 1975). From our observations it is not clear whether the parents already start to moult their primaries and rectrices in the last period of parental care. At least one of these parents is included in our category of 14 "presumed non-breeding adults" (see methods). Five birds within this category had a complete set of primaries and rectrices and possibly these were birds still feeding fledged juveniles. If adults do not moult during the whole breeding cycle, they wear the same primaries and rectrices for at least 14 months.

If Greater Frigatebirds have a biennial cycle (Nelson, 1975) then the period of moult must be less than 10 months. Adults in this period of their cycle probably are found in the category called by us "presumed non-breeding adults". However, this category may be rather heterogeneous as it may contain: birds that failed to breed, birds that failed at breeding attempts, birds that just have reached adult plumage, and possibly also parents feeding fledged young. In 9 out of 14 birds of this category we see active moult in primaries and/or rectrices. In fig. 4 moult of 8 of these birds is shown. The 6 birds with active moult all show 2 moult waves and consequently 3 feather generations. The 2 not moulting birds have 4 feather generations, which is more similar to the breeding birds that also mostly have more than 3 feather generations (see fig. 5). If the moulting period is less than 10 months and all primaries are renewed within this period, then on average one primary is renewed in less than one month. When there are two moult waves and two feathers are replaced simultaneously, then on average the moult waves proceed with a speed of 1 feather in less than 2 months.

In the category subadults we probably have birds of different year classes. Some are very light (fig. 1) like fledged juveniles; others have more dark feathers (fig. 2) and some have nearly attained adult plumage. Judging from body plumage the first, fifth and sixth bird (the latter shown in fig. 1) of fig. 3 were subadults that were at least one year younger than the others (cf. fig. 2). These 3 birds showed a pattern of primary moult that differed from that of the other subadults. They all had a feather generation of 8 feathers. The others had 7 feathers or less in one generation. The subadults of fig. 3 had never more than 3 feather generations, just as the active moulters of "presumed non-breeding adults".

The start of a new moult wave at $P_{1}$ seems to be independent of how far the outermost moult wave has proceeded. For instance $P_{10}$ may still be old while $P_{1}$ is being renewed.

Many questions remain. At what age does the 


$$
\text { ó ó }
$$

PRIMARIES

12345678910

R $\bullet 000000000$

L

R

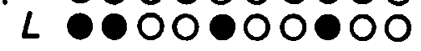

$R \quad 0000000000$

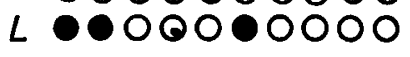

$R L \bullet \bullet 00 \bullet 00 \bullet 00$

$R$,

L 1000000000

RL $\bullet \bullet 00 \bullet 0000 \bullet$

${ }^{R}$ L $8: 000000008$

RL $\bullet \bullet 000 \bullet 0000$

$R L \bullet 00000 \bullet 000$

$R \quad 000000 \bullet 000$

L $\bullet 0 \bullet 00 \bullet 0000$

$R L \bullet 0 \bullet 000 \bullet 000$

$R \quad 000000000$

L

RL $100 \bullet 00 \bullet 000$

$R L \bullet 000000 \bullet 0 \bullet$

$R \quad 0000000000$

L

RL $100000000 \bullet$

$R \quad \bullet 0000 \bullet 0000$

L

RL 1000000000

$R L \bullet 000000000$
우우

PRIMARIES

12345678910

${ }^{R}$ L :8000008000

RL $\bullet \bullet 0 \bullet 000 \bullet 00$

$R L \bullet \bullet 00 \bullet 00 \bullet 00$

RL $100000000 \bullet$

$R L \bullet 0 \bullet 000 \bullet 000$

RL 0000000000

${ }^{R}$ L 800800000000

R 9000000000

L 100000000 .

${ }^{R}$ L 80000000000

R L

${ }^{R}$ L 800000080000

RL $10000000 \bullet 0$

$R \quad 0000000000$

L 1000000000

RL $1000 \bullet 00 \bullet 00$

RL $\bullet 000 \bullet 000 \bullet 0$

R $\bullet 000000000$

L $10000 \bullet 0 \bullet 00$

RL $\bullet 000000 \bullet 00$

Fig. 5. Moult of primaries of 36 adults with small young or egg; legends as in fig. 3. 
juvenile Greater Frigatebird start to moult? The 2 fledged juveniles caught had a set of primaries all of the same age. Greater Frigatebirds on Genovesa have an annual breeding season with eggs from March to August. These 2 juveniles thus had an age of 12 months or more and had fledged for 6 months or more. As dependency in the postfledging period has a duration of up to 10 months (Nelson, 1975) many more flying juveniles from this period have to be studied to make sure whether they already start moulting in this stage of their life or not. How fast does moult proceed once the juveniles have started moulting? Does a second wave start before the first wave has reached $P_{10}$ and if so, how far has the first wave proceeded then? In what stage of their cycle do adults start to moult? Possibly already in the period they still are caring for fledged juveniles.

To answer these questions future research should be concentrated on studying fledged juveniles, subadults, non-breeding adults and parents feeding fledged juveniles.

\section{ACKNOWLEDGEMENTS}

We thank the Director of the Charles Darwin Research Station and his staff (in particular Dr. José Cañon) and the Intendente del Servicio del Parque Nacional Galápagos for their cooperation and for arranging inter-island transportation.
Drs. Dittie Rebel assisted in the field and took care of us in many ways. Dr. Ian Ball kindly corrected the English.

This is contribution no. 245 of the Charles Darwin Foundation for the Galápagos Isles.

\section{REFERENCES}

Coello, F., C. Hernandez, M. L. Ortega \& TJ. de Vries, 1977. Reproducción y frecuencia alimenticia de Fregata minor en Genovesa y Fregata magnificens en Seymour, Galápagos. Rev. Univ. Católica Quito, 5 (16): 71-110.

Dinmond, A. W., 1971. The ecology of seabirds breeding at Aldabra Atoll, Indian Ocean. (Unpubl. Ph. D. thesis, Aberdeen University).

Nelson, J. B., 1975. The breeding biology of frigatebirds a comparative review. Living Bird, 14: 113-155.

Stresemann, E. \& V. StresemanN, 1966. Die Mäuser der Vögel. J. Orn., 107 (Sonderheft): i-vii, 1-448.

\section{APPENDIX \\ Leyenda de las figuras}

Fig. 1. Hembra subadulta de Fragata Pequeña, Isla Genovesa, Agosto 1977. Fotografía de J. de Korte.

Fig. 2. Hembra subadulta de Fragata Pequeña con marca de identificación, Isla Genovesa, Agosto 1977. Fotografía de J. de Korte.

Fig. 3. Muda de plumas primarias y remeras ( $R$ es derecha, L es izquierda) de 20 subadultos; la muda se realiza en ondas desde la parte más interna $\left(P_{1}\right)$ hacia las primarias más externas; a = primaria más vieja en el proceso de generación de las plumas, $b=$ resto de primarias, $c=$ pluma ausente, $\mathrm{d}=$ remera relativemente vieja, $\mathrm{e}=$ remera relativamente nueva, $1 / 2=$ pluma creciendo.

Fig. 4. Muda de plumas primarias y remeras de 8 aves adultas en época fuera de reproducción; leyenda como en la fig. 3.

Fig. 5. Muda de plumas primarias de 36 adultas con crías juveniles o con huevos; leyenda como en la fig. 3. 